\title{
Local conflicts and national consensus: The strange case of circular economy in Sweden
}

\section{Johan Niskanen, Jonas Anselm and Duncan McLaren}

\section{Abstract}

Swedish press debate regarding the idea of a 'circular economy' is analysed to enable critical reflection on the development and use of the concept. We examine how actor positions formed around ideas of increased circularity. Using press material from 2012 to 2019 we identify positions on circular economy taken by Swedish companies, public authorities, political parties, and opinion makers. Our analysis reveals convergence amongst these actors at the national level despite ongoing situated local environmental conflicts. We show that this convergence is enabled by the convening power of ambiguity, which characterizes the use of circular economy ideas as an 'floating signifier' in the debate. In Sweden ideas of a circular economy may have been deployed by resilient capital to harness an otherwise economically disruptive process, as a new expression of ecological modernization. Further research into the political economy of circular economy ideas is encouraged.

Key words: circular economy, Sweden, environmental politics, natural resources

\section{Introduction}

In this article we critically reflect on the press debate about the idea of a 'circular economy' (CE) in Sweden. In the past decade the idea of a CE - as a means to reduce the environmental impacts of the industrial economy by designing out waste and minimizing inputs of nonrenewable resources - has moved into mainstream debate in many countries, especially through the introduction of policies such as China's Law on Promoting Circular Economy (2008) and the European Union' Circular Economy Action Plan (2019).

A CE is commonly framed as a novel production model focused on circular flows of materials - an alternative to a conventional 'linear' economy in which resources are extracted, used and then disposed of (Ellen MacArthur Foundation, 2013). Through the redesign of production processes and products triggered through appropriate regulations and tax reforms, CE approaches are anticipated to reduce waste, increase employment and sustain business competitiveness (Korhonen et al., 2018; Stahel, 2013; Winans et al., 2017).

Circular economies have increasingly become a topic of interest for academics, not least in this journal (Geissdoerfer et al., 2017; Ghisellini et al., 2016; Tukker, 2015, etcetera). Focus has often been placed on technological aspects and environmental implications of cleaner product design, business models, and industrial symbiosis (Bocken et al., 2016;

Lewandowski, 2016; Murray et al., 2017), as well as on developments in 'circularity pioneer' country China (Geng et al., 2013; Su et al., 2013; Yuan et al., 2006).

Academic literature is predominantly unreflexively positive about CE ideas. Nonetheless some scholars have argued that the idea of a CE is thermodynamically naïve (Skene, 2018), or inevitably comes with rebound effects undermining environmental benefits (Zink and Geyer, 2017). It has also been criticized as a distraction from other (more) important issues, e.g., equity (Moreau et al., 2017) and for broadly failing to engage with social implications and depoliticizing sustainability challenges (Hobson and Lynch, 2016). Finally, it has been argued 
that a CE is a sustainability illusion if economic growth is not addressed as a problem per se (Temesgen et al., 2019).

Scholars have reviewed the emergence and development of CE narratives. Rieke and colleagues (2018) trace the history of CE ideas from a focus on waste management to its current revival as a response to resource depletion, and highlight the diversity of activities and definitions. Blomsma and Brennan (2017) similarly identify the CE as a 'umbrella concept' used by multiple stakeholders to encompass diverse activities. Stakeholder narratives of circular economies have been mapped at the European level (Lazarevic and Valve, 2017) but not yet in leading proponent countries. This paper helps address this gap, with a case study of Sweden. We study how key business and public actors perceive and contribute to understandings of the idea through an analysis of the CE debate in national and business newspapers. Our analysis highlights that the CE concept is sufficiently flexible as to provide a valuable convening narrative, however also therefore so vague that it may risk political capture, in a way which could compromise its normative value.

The case of Sweden is of special interest as an early adopter of an ecological modernisation (Mol and Sonnenfeld, 2000) approach to environmental and climate issues (Anshelm 2002; Hysing, 2014; Lidskog and Elander, 2012; Lundqvist, 2004), which has more recently established a goal of being at the forefront of international CE development and implementation (SOU 2017:22). Sweden also has a long history of attempts at increasing circular material flows in society through recycling (e.g., Johansson, 2011; Sjöstrand, 2014).

In the next section we present the recent history of environmental politics in Sweden. We then describe our method for analysis of press material, before using that material to analyze the CE debate in Sweden. We continue the paper with a discussion of the Swedish CE debate before we conclude with some critical thoughts on challenges for the future study of circular economies.

\section{Background: From consensus to conflict in Swedish environmental politics}

In the $20^{\text {th }}$ century, the strongly Keynesian Social Democrat party dominated Swedish politics (Anshelm, 1995). An industrial society was maintained with increasing attention to sustainable processes and products, based on a belief that Swedish sustainability-oriented enterprise could flourish, delivering employment and economic growth, through green exports in an increasingly environmentally aware global competitive market. This position justified comparatively strict environmental regulations, interventionist economic and fiscal management, and active employment policy.

Swedish centre-right liberal and conservative parliamentarians also argued that sound environmental politics could be achieved through competition between businesses developing green technologies - but favoured a more unregulated market driven by consumer choice (Anshelm, 2012). As opposed to active employment policy they supported lower taxes on work and more favorable business conditions.

Despite some reservations about the value of economic growth, the Green Party has also endorsed green Keynesianism, but typically with more stringent environmental requirements 
than proposed by other parties. In recent years, in political coalition with the Social Democrats the Greens have taken a pragmatic market-oriented stance, with few eco-socialist elements (Anshelm, 2012).

All the mainstream Swedish parties have broadly embraced forms of ecological modernization in the area of environmental politics. Ecological modernization arose as an analytical concept in social science (Mol and Sonnenfeld, 2000) but was adopted in Sweden by the social democratic government in the late 1990's as a positive narrative vision of a green growth-based welfare state (Anshelm, 2002). Ecological modernization was introduced by Social Democrats but was largely supported by other political parties, albeit repurposed to suit liberal, conservative, or green agendas. This means that environmental problems have been interpreted as administrative issues to be solved with the aid of state interventions to create and structure consumer markets appropriately.

Against this background, one might expect environmental issues to be depoliticized (Ranciere, 1995; Swyngedouw, 2010), and environmental conflicts limited. On the contrary, and especially in the last decade, there has been a strong repolitization of environmental issues in Sweden, expressed through local conflicts over controversial extraction and processing projects that have brought economic and resource concerns into conflict with biodiversity and sustainability aspirations (Anshelm et al., 2018a; Haikola and Anshelm, 2016; Persson et al., 2017; Anshelm and Haikola, 2018).

On the island of Gotland, for example, there has been a decade-long intense environmental conflict that reached not only Sweden's highest courts but even the European Court of Justice. An international company in the limestone industry had long-running plans to establish a quarry in the Ojnare forest, in an area that the Swedish Environmental Protection Agency (EPA) had simultaneously sought to designate as Sweden's next national park (Anshelm et al., 2018a).

In this conflict, the mining industry, business organizations, and the Metal Workers' Union supported increased extraction for resource supply, economic and employment reasons (Anshelm et al., 2018a). The other side of the conflict brought together heterogeneous actors in an alliance between local groups on Gotland, environmental activists, the Swedish Society for Nature Conservation, the EPA, the Swedish Agency for Marine and Water Management, and local authorities. They argued that a quarry would harm both biodiversity and long-term employment opportunities.

A similar pattern of environmental conflicts over natural resource extraction and processing projects involving similarly heterogenous coalitions could be found in many other parts of Sweden at the time; with examples including iron ore extraction at Kallak (Haikola and Anshelm, 2016; Persson et al., 2017); oil refinery expansion in Lysekil (Nyberg, 2019); and the extraction of rare earth metals at Lake Vättern (Anshelm and Haikola, 2018). The local protest groups in general emphasized circularity rather than linearity: industry ought to first and foremost handle resources already existing as 'scrap' or shutdown infrastructures in society before they turned to extracting primary resources (Anshelm et al., 2018b).

Local resistance groups have coordinated nationally through loose networks where they exchanged experiences and skills. They have influenced public opinion, engaging national environmental organizations, national political parties and authorities. Political lobbying and 
legal challenges have reached parliament and the courts, further amplifying the conflicts to such a degree that resource extraction companies have expressed fear that mineral extraction would be banned in Sweden (Anshelm et al., 2018a).

These natural resource conflicts have exposed divisions between parties that otherwise promoted ecological modernization. The Green Party and the Left Party sided with local environmental resistance groups while centre-right parties sided with industrial interests. The Social Democrats held an ambiguous position in the local conflicts. In the Ojnare conflict they first sided with labour and business interests as per their national mineral strategy, while they in the end decided to classify the forest as a Natura 2000 protected area (Anshelm et al., 2018a), which was an obvious setback for industry interests. It is in this area of tension between a green industry ideology and heated local environmental conflicts over natural resource and processing projects that the debate about $\mathrm{CE}$ is playing out.

\section{Methods: analysis of press material}

The analysis in this study is based on printed press material with a focus on opinion pieces authored by and attributed to company representatives, public authorities, parliamentarians, and environmentally minded opinion makers. Material was collected using the Retriever search engine, which is the largest digital news archive in the Nordic region collecting news from print and digital editorial media back from the 1980s (Retriever, 2020).In the Retriever archive we searched all major Swedish newspapers, the business press and environmental journals for mention of the phrase 'circular economy' ('cirkulär ekonomi' in Swedish). This focus was chosen as these media are historically where environmental debate in Sweden has taken place (and these media are also prominent in contemporary online debate). The study period was set up to the research date in 2019 , beginning from the first mention of the term in the Swedish press in 2012.

From a total of 2000 articles we made a first read-through and identified almost 300 relevant articles that have formed the basis of our qualitative content analysis (Mayring, 2004). In this type of analysis, the relevant articles are assumed to represent the valuations and statements of key actors at the time. Not all the articles are presented here, but those directly referenced in this study (see Appendix A) are illustrative of the major positions and value patterns present in the CE debate. We did not conduct any quantitative content analysis of the material (Riff et al., 2019).

In a first step we closely read the selected 300 articles to establish the relevant content. Those parts of the material considered to be particularly significant in relation to the purpose of the research were marked (see Appendix A), repeatedly read, and coded manually into topics or themes. Thus, in this second step, a number of recurrent topics or themes were identified. These were: Swedish companies' demands for CE legislation; a CE as a way to strengthen Swedish companies' international competitiveness; environmental organizations' and the environmental movement's confidence in the economic and ecological opportunities of a CE; the Swedish authorities' positive assessment of the potential of a CE; Swedish political parties' approach to the proposition of a transition to a CE; the notion of Sweden as an international $\mathrm{CE}$ pioneer; alternative movements ambivalence to the idea of a $\mathrm{CE}$; the strong convergence of Swedish stakeholders around a CE as a solution to both economic and ecological problems; 
and finally, explicit cooperation around a CE between organizations and actors who tend to take opposite environmental political positions and represent different interests.

In a third step, these different themes were compared, and three overall categories were thereby established. Each theme touched on one or more economic, political and/or ecological aspects. We therefore chose to present the account of our analysis under these three category headings. Each category contains several themes and each theme can appear within one or more categories in our analysis. As an analytical framework these categories help us take into account opinions and agendas from actors that may have divergent core interests. The categorisation is not to be understood as three independent topics but rather as different areas of emphasis in the debate. The method is iterative and not linear: we repeatedly returned to the various steps to reinterpret the material to reach a gradual deepening of the analysis.

Lastly, when analysing the categories, we particularly took notice of strong and recurring statements, contentions and contradictions, in order to identify the most affected and influential actors and their positions. Through this, we were able to distinguish positions on a CE taken by Swedish companies, public authorities, political parties, and opinion makers (our 'key actors').

The next section follows a structure driven by the content of the analyzed press material, presenting the positions taken by key actors in the three identified categories. As we present the material we interact with it critically. The categories are first outlined in terms of narratives of what a CE means for different actors, second we discuss these findings against current social science literature, thereby highlighting different economic, ecologic and political positions making for a deeper and broader understanding of how CE concepts are being developed and understood in Sweden.

\section{Results}

In what follows we describe and analyse the debate that addresses a CE in Sweden, with a focus on the positions taken by the key actors in relation to the identified categories.

As of the early 2010's, company representatives, public authorities, parliamentarians, and environmentally minded opinion makers in Sweden all began to express support for the idea of a CE. These actors at times expressed differing understandings of the meaning of circularity, but there was, and remains, significant convergence on the central idea that a $\mathrm{CE}$ is desirable and should be pursued and implemented. Here we examine how this convergence emerged and manifested, what arguments were presented for a CE transition, and what measures were recommended for this to be realized.

\subsection{The economics of circularity}

Following several years in which CE narratives increasingly featured in economic and political commentary, in 2016, the Ministry of Enterprise and Innovation released a 'smart industry strategy' which presented a CE as a way to "create solutions for societal challenges, as well as bring competitive advantages and opportunities for sustainable growth" (GOS, 2016:19). Representatives of the Swedish Recycling Industries Association proclaimed that a CE would play an integral part in the strategy: "Sweden could become the world's most 
circular economy - something that is absolutely central, not least for the climate and jobs" (Article 1).

The same spring, the Royal Swedish Academy of Engineering Sciences, large companies with a marked Swedish identity operating in the global market, such as Volvo, H\&M, Alfa-Laval and Södra, domestic companies, representatives of research councils, as well as the EPA and the Swedish Agency for Economic and Regional Growth, co-signed a petition in support for greater CE action. In their support for a more circular economy they proposed that Sweden should be a "leading nation in resource efficiency", (Article 2). Overall such grandiose but vague expressions dominated the debate.

Corporations demanded new environmental regulations, including a CE strategy, so that "companies that have so far been profitable dare to invest in the growing fossil-free economy” (Article 3). If policy didn't favor Swedish companies, they argued, the country could lose its deemed leading position on the increasingly fossil-free world market. The sustainability manager at IKEA, Jonas Carlehed, stressed that national legislation and proactive politics would play a key role in fostering a new economy:

"We need a new economic model which is not dependent on virgin materials, where products are increasingly based on renewable materials and energy, where energy use is maximally effective, where products are designed to last a long time, and we need to facilitate recycling, dismantling, reuse and reconditioning" (Article 4).

For corporations, appealing to national interests made sense since much of natural resource legislation takes place at the governmental level. Companies continually argued that for a $\mathrm{CE}$ to be successful (Article 5), tougher environmental regulations were required to "force companies in the right direction" (Article 6), and "stricter climate objectives in the EU" was invoked "for the sake of competitiveness" (Article 3). While even neo-liberal business interests do not eschew regulation (Harcourt, 2011; Mirowksi, 2013), this was in great contrast to the heated legal conflicts over natural resource extraction and processing projects playing out all over Sweden at the same time.

CE was also presented as a contribution to global climate mitigation. Representatives of Axfood, H\&M, Ikea, NCC, SSAB and others argued that the Paris agreement could not be achieved at all without re-use and recycled materials, while researchers from the Stockholm Resilience Center argued that a CE was one of the prerequisites for reaching the IPCC's 1.5degree target (Articles 1, 3, 5, 7-11). From this position, a sustainable transition to a circular society required political initiatives and actions by cities, industries, and countries, amongst other actors, but could not be left to individual consumers in the market.

At the practical level, however, the examples of desired regulation offered were much less ambitious. For example, Carlehed of IKEA asked for more circularity,

"to enable companies to take responsibility for product repair, resale, or recycling, regardless of whether the consumer now regards the product as waste... it is of great importance for a functioning circular economy not to monopolize the collection of reusable products, materials and resources" (Article 4).

Despite large business interests' apparent commitment to CE as a strategy, there are noticeable lacunae in the debate. For example, while local environmental activists identify the 
linear economy as the enemy (Anshelm et al., 2018b), there are no resource extraction businesses, nor any other business interests directly arguing that increased circularity should lead to more sustainable natural resource management or a reduction on the dependence on now contested (Swedish) resources. CE is promoted in the debate by resource-consuming businesses and the forest industry, the steel industry, and the mining industry, alike, but not in relation to local conflicts.

There is also a noticeable lacuna about how the transition to circularity will be financed - a question ignored behind simplistic claims that reducing waste will deliver financial savings, e.g., "the recycling industries expect that SEK 11 billion could be 'recovered' within a period of 20 years - provided that Sweden is moving towards an increasingly circular economy" (Article 12).

These examples act as reminders of the role regulation plays for market formation in the global economy (Harcourt, 2011; Mirowksi, 2013), suggesting that ideas of circularity might be attractive for corporate actors as a sustainability strategy only if designed and adjusted in line with their market interests. There is little to gain for most companies in publicly connecting the general idea of CE with current Swedish conflicts over natural resource projects. The business sector therefore advocates for increased national regulation of a $\mathrm{CE}$ even while specific companies continue to defend linear economy practices in legal battles over local extractive activities. This leaves questions of huge environmental import: for example, what would a CE mean - and over what timescales - for economic growth, overall extraction volumes, and the specific localities where extraction currently occurs or is proposed?

Business arguments for enabling regulation and support from government presume that such measures would stimulate innovation and change consumer behavior, releasing profitable and employment-generating potential for CE practices. From an economic perspective, a CE was thus presented as something that business could generally support because it would be profitable, reducing resource dependency and waste management costs, while increasing international competitiveness, with little effect on local linear practices. This suggests that for business the $\mathrm{CE}$ ideal is government policy which focuses on recycling, recovery, and the consumer behaviour end while not imposing new rules on extraction or export of resources.

\subsection{The politics of circularity}

Between 2014 and 2019 the Social Democrats and the Green Party were in a coalition government (since 2018, a minority government). Their main political opposition was the centre-right liberal conservative political alliance. At the same time as political tensions over local natural resource extraction and processing projects were high how did parliamentarians react to stricter environmental policy demands from business interests regarding a CE?

The Green Party argued already in early 2014 for a more circular economy prioritizing reuse and repair (Article 13), and their youth party spokesperson argued in Sweden's largest daily that

"economic growth without increased emissions is now possible. Thus, a new green economic critique is needed. Instead of growth criticism, the discussion of the future should be more about resources, consumption and circular business models" (Article 14). 
Historically, the Green Party built their political programme on climate and environmental issues (including more circularity), but their impact on economic policy was limited. So, when several of the largest Swedish companies became advocates of a CE, a window of opportunity opened for the party to become economically relevant. The Greens' Per Bolund, Minister of Financial Markets in the coalition government, declared that the party would address its general crisis of confidence and declining popularity by showing leadership in the economic debate (Article 15). This was done though the presentation of a "green economy package" with a CE as the overall theme and increased support for services promoting recycling and sharing of resources through mechanisms such as such as tax breaks for repair, and support for 'sharing economy' platforms for carpooling and accommodation.

In January 2016, the Green Party's policy shift can be said to have had a first impact, when the government appointed a committee with the task of proposing new instruments and laws to promote increased re-use and prevention of waste, to thereby achieve "a more resourceefficient and circular economy" (Dir 2016:3). The task of the investigation was primarily to regulate the conditions for consumer products, but the committee was also to investigate measures for decoupling economic growth and environmental degradation, which was entirely in line with the Green Party's claims that sustainable growth would be possible in a more circular economy.

In March 2017, the CE committee reported (SOU 2017:22). It suggested several concrete proposals: for example, tax deductions for repairs and second-hand sales; measures to facilitate carpooling and to simplify household waste reduction; reinforced consumer protection in secondhand consumption; and more. The long-term goal set by the committee was to support a CE transition. The investigation also led to the establishment of an advisory board for the government: The Commission for the Circular Economy, with the purpose of strengthening the transition to a resource-efficient, circular and bio-based economy.

Later in 2017, the Green Party presented a comprehensive proposal for a new economic policy with the goal that Sweden would switch to a completely circular economy:

"The Green Party has begun a historic transition of Sweden... the tax on emissions is increased while the tax on enterprise, jobs and repairs are lowered. We have raised the environmental budget by 82 percent... We have propelled a climate law, an agreement of 100 percent renewable electricity and invested more than any other country per capita on international climate support... The next step is to change the entire economic policy", (Article 16)

Thus, the large corporations and the Green Party now seemed to have common interests and set the tone of the debate on CE since 2017, something that just a few years previously would have seemed completely implausible due to them considering each other with the greatest suspicion (Anshelm 2012). This was visibly in contrast to the heated arguments continuing elsewhere between business interests and the Green Party over natural resource extraction projects and suggests that the $\mathrm{CE}$ concept may be acting here as an ambiguous convening device.

Even though the Social Democrats commissioned the investigation, they kept a lower profile than their Green Party coalition partner. The Minister of Infrastructure, Social Democrat Anna Johansson did however declare that their "basic attitude" was that they were positive towards 
a CE (Article 17), and Minister of Enterprise, Social Democrat Mikael Damberg claimed that a transition to more circularity was "necessary", not least to ensure economic competitiveness and employment (Article 18).

Later, in their election manifesto for 2018, the Social Democrats also included several proposals for increased circularity, such as a deposit scheme for used mobile phones and electronic scrap, tighter legal requirements on packaging, and more efficient textile recycling (Articles 19-20). Labour interests also generally kept a low profile in the CE debate; although the Swedish Trade Union Confederation endorsed the Government-appointed CE committee investigation and while arguing that labour interests should be safeguarded in a transition to more circularity (LO, 2017).

Although the CE investigation solidified a convergent position between large companies and the red-green government, the former still demanded stricter regulations and more company control. For example, Carlehed of IKEA argued for stricter waste rules in order to "create the conditions for an economic, sustainable and circular society that in turn supports Sweden's business and competitiveness" (Article 4). And representatives for Electrolux and the Association of Swedish Engineering Industries advocated for a revision of European laws, rules and policies to "promote more circular and sustainable free trade solutions..." (Article 21).

While seemingly contradictory, one way to understand this call for more legislation is to see it as a practice of what we can call 'resilient capital': a mechanism for increased control over resources by companies facing political pressures. Against a background of mounting climate change policies, local environmental conflicts and political support for circularity, industry wanted to shape a political agenda to secure control over resources and investments. For resource-using industries such an agenda offers an opportunity to establish new product niches. These examples hint at the pragmatism guiding the convergence of understandings in the debate, building on the ambiguity of the CE idea. Temporality of course matters here: even calling for national legislation pushes the moment of corporate adoption of a CE into the future, which could be of particular importance for resource extracting industries.

In contrast, the liberal and conservative parties who have long been positioned as the most large-business-friendly had relatively little to say about a CE. In neo-liberal spirit, they interpreted the $\mathrm{CE}$ concept as being about making it easier for individuals to recycle household waste (Article 22). The centre-right liberal conservative political alliance suggested consumer solutions and otherwise largely eschewed government regulation and legislation:

"We propose stricter requirements for collection systems, increased accessibility and equal service throughout the country. This service should be free of charge for the households and the guaranteed service level financed by the producers... [and we propose] increased innovation in the recycling sector through deregulation" (Article 23).

In this respect, the liberal and conservative parliamentarians underlined individual freedoms far more than did the business interests they are often assumed to represent. They even faced surprising criticism from free market think tank Timbro who claimed that they showed no political initiatives on the $\mathrm{CE}$ issue "despite the EU facing major choices in the coming years, [liberal and conservative parliamentarians do] not appear to have their own ideas of the direction in which cooperation should be driven" (Article 24). 
It seems that rhetorical radical market liberalism regarding environmental concerns had perhaps outlived its value for the large companies, which anticipate having to change their production in the foreseeable future, while centre-right politicians remained as supporters of orthodox neoliberalism. Instead, the companies that supported a CE policy found sympathy within the red-green coalition, especially in the small and previously marginalized Green Party, to introduce enabling regulations.

While business interests went further in their rhetorical support for circularity than the redgreen coalition, and while the liberal-conservative alliance mostly ignored CE ideas, overall there was convergence in the debate. The underlying environmental politics was a pragmatist and rationalist view of 'green industry' policy shared by corporations and parliamentarians alike, despite divergent positions on local resource conflicts.

\subsection{The ecologics of circularity}

Several environmental NGOs and the EPA joined the corporations in adding pressure on the politicians to regulate for a CE (Article 25). Despite the preceding and ongoing environmental conflicts over natural resource extraction, the Swedish Society for Nature Conservation (SSNC) even published joint articles with industrial actors on several occasions (Articles 11, 26). A specifically noteworthy episode was when the Secretary General of SSNC, Svante Axelsson, together with SVEMIN (the Swedish industry association of mines, mineral and metal producers) published an opinion piece in support of underground Carbon Capture and Storage and "fossil-free mining" as a form of CE:

"The development of the circular economy is also an important key in creating a completely fossil-free mining and mineral industry... However, the development will take time and be capital intensive. Therefore, it is important that politics facilitates the change through concrete measures" (Article 26).

Here SSNC support the idea that even mining can be somehow 'circular', while in the local conflicts over natural resource extraction and management they emphasize recovery and reuse of materials in opposition to resource extraction (Anshelm et al., 2018b). Again, we see in this contradiction the potential ambiguity in the CE concept, in which it might simultaneously hint at less climate polluting mining activities, while also legitimating a necessarily slow transition in the extractive industries to maintain jobs and profits.

One individual who came to symbolize the convergence between representatives of environmental interests, industry and the government was Anders Wijkman. In his roles as the chairman of the Club of Rome in Sweden, chairman of the Swedish Recycling Industries Association, and chairman of the national cross-party Committee on Environmental Objectives, Wijkman became a prominent spokesperson for the idea that Sweden must adopt a circular economy, as replacement for a linear one that had exhausted both its economic and ecological possibilities (Articles 27-29). According to this position industry was the main driver of CE processes and politicians ought to support their endeavors through e.g., valueadded tax exemption on recycled materials (Article 29). This exemplifies an understanding of CE ideas as inherently good, and therefore something that ought to be supported by politicians. 
Although opinion makers such as Wijkman, and Johan Rockström of the Stockholm Resilience Centre, have also expressed criticisms of economic growth (Articles 30-31), the specific measures they propose to promote circularity reflect a support for incremental solutions apparently compatible with continued growth, such as increased energy efficiency, carbon pricing, and cleaner technologies (Articles 31-32). Arguably their support for a CE is expressed as a quest for 'eco-efficiency' in which circularity is pragmatically coopted into the existing economic system, rather than actively seeking to transform it.

These opinion-makers acted as bridge builders between industry, government, and environmental interests, providing both economic and environmental arguments for the introduction of a CE. For example, Wijkman, representatives of IKEA, the Swedish union of forestry, wood and graphical workers, and the Stockholm Resilience Center together argued that a CE transition would lead to the creation of 100,000 new green jobs (Articles 9, 28, 33). This highlights another way in which the ambiguity of CE ideas can 'hide' political contradictions and bring together different interests. A CE can be understood simultaneously as a way to resist and even close down extractive activities, but also as a way to rebrand those activities as a fundamental part of Sweden's sustainable future (with a gradual transition in business models that maintains jobs and profits).

Johan Ehrenberg, an ecologically and socialist-oriented opinion maker, newspaper editor and renewable energy entrepreneur, extended the argument: through more circularity, 'economic growth' would become a solution to global ecological and social problems (Article 34):

"With enforced reuse [of materials] and a circular economy, one [planet earth] is enough [to sustain humanity]. Growth can be infinite in a finite world because growth is about goods and services being made smarter and smarter and giving people more and more time for other than toil" (Articles 35).

The idea of compatibility of circular economic growth with environmental considerations received strong support from environmental organizations, environmentally minded opinion makers, large company CEOs, and the Minister of Environment, amongst others (Articles 2-5, $11,21,25,28-29,36-39)$.

Despite this optimism, the converging CE narrative in Sweden did face criticism. But critical voices were few and surprisingly uninfluential in the CE debate. Even when mainstream economists from Swedish academia and the state agency the National Institute of Economic Research objected to the dominant narrative, their views - that achieving circularity, even if viable, would be of no economic benefit since some industry sectors would gain from it while others would lose (Articles 40-41) - had little impact.

Marginal criticism came also from the extra-parliamentary left arguing that CE rhetoric was not being translated into practical action (Articles 42-46) but risked becoming a new 'greenwashing' tool for CE advocates such as H\&M and Volvo (Article 47). But even here the concept of CE was being mobilized positively: in this case in support of more disruptive societal and environmental change. Yet, even the critical voices did not connect a $\mathrm{CE}$ to the local environmental conflicts playing out during the same period in Sweden.

The overwhelming consensus was that the linear economic model, based on the extraction of new natural resources and rapid consumption and turnover of products, had become an economic and ecological impossibility, unable to support a growing world population. In 
contrast, a circular economy was seen as the way to continue to provide goods and services to sustain and spread high levels of welfare.

\section{Discussion: Interpreting the circular economy debate in Sweden}

We have analyzed the CE debate in Swedish press material between the years 2012 and 2019 with a focus on opinion pieces by company representatives, public authorities, political parties, and environmentally minded opinion makers. Despite the recent history of local environmental conflicts in Sweden, in the national debate the idea of CE was (almost without exception) uncritically incorporated in a pre-existing narrative in which global market competitiveness could be prioritized, perfectly balancing within planetary ecological boundaries (Anshelm, 2012).

Within this narrative, the CE concept promised to erase the need for conflicts between economic demands and ecological considerations. Key Swedish actors have converged on this common narrative from different directions. Green Party representatives increasingly acknowledged that large corporations, and not just small business, had to play an important positive role in the response to climate change. In turn, large companies adapted to a certain extent to the Green Party's views on resource use and the role of environmental legislation in securing conditions for production. Extractive and resource-consuming businesses alike supported increased circularity.

Social Democrats supported the idea of more circularity through commissioning a CE investigation. And they generally endorsed aiming to increase eco-efficiency and circularity in the existing economic system, as advocated by environmentally minded opinion makers and large business interests. Liberal and conservative parliamentarians underlined individual freedoms in the CE debate, which set them apart from business interests. But overall the CE debate was, and is, characterised by a notable convergence around the idea that the implementation of a CE could proceed without political disputation.

The CE narratives in Sweden broadly reflect the historic evolution from waste management to resource management identified by Rieke and colleagues (2017), and the themes of idealized circularity, new roles for consumers, economic growth, and renewal though competitiveness identified at the European level by Lazarevic and Valve (2017).

Thus, the local conflicts over natural resources raging in Sweden at the same time appear to have had no direct impact on the CE debate. Rather these debates are running parallel, as to a large degree the same political parties, the same companies, the same industry organizations, and the same environmental organizations, which are opposed in local conflicts, are in full agreement on the implementation of a CE. This disconnect between CE politics and natural resource politics in Sweden is all the more striking because Sweden is - in contrast with the EU as a whole - a net resource exporter. This all begs the question: how can we explain that the debate on CE in Sweden is seemingly so depoliticized?

\section{Conclusion: Circularity, ambiguity and resilient capital}

We have highlighted several ways in which the ambiguity of the CE concept has enabled at least a rhetorical agreement amongst key actors in the press debate. It could be argued that 
this extends to the apparent tension between local conflicts and national CE rhetoric to terminate the linear (extractive) economy. Locally, heterogenous groups are resisting extraction, arguing that biodiversity and even long-term economic wellbeing are threatened by it, and that resource recycling is preferable; while industry insists that new extractive developments are essential for jobs and growth. Nationally in contrast, the idea of a CE allows the Greens and industry together to call for growth and sustainability based on a vaguely articulated, and potentially gradual, transition away from extractivism involving more recycling of resources, and reuse or restoration of mining facilities in activities such as carbon storage.

It is possible that the Greens see a CE as a 'trojan horse' which can transform business and bring an end to extractive activities through the leverage of manufacturing companies adopting circular practices. Or that businesses see it as a greenwashing tool which allows them to maintain a green image nationally and internationally, despite local conflicts. Neither goal would be openly discussed. In this respect it may be significant that the practical measures of circularity proposed and implemented so far engage with eco-modern urban sensibilities about repair, recycling and consumer products; rather than with policies and practices of extractive industries in remote and rural settings.

We do not see the CE debate as something generated by the local conflicts, although this tension might have contributed to the specific ways in which CE ideas has been adopted in Swedish environmental discourse. However it does seem likely that CE ideas have been adopted as the most recent expression of the long-standing ecological modernization discourse, which in Sweden has consistently acted to depoliticize national environmental policy, and obscure any contradictions between Sweden's role as a major exporter of natural resources (particularly iron, copper and forest products) and its self-image as an environmental leader.

All this suggests that critical questions regarding both the business economics and politics of a $\mathrm{CE}$ transition remain to be answered. In the debate the CE concept is presented as a managerial and technocratic, matter-of-fact issue, rather than a social and political issue and it becomes seemingly unpolitical. However, the practical implications of a CE for extractive industry in Sweden remain entirely opaque despite the potential for situated conflicts, not only over extractive activities but also over industrial scale reprocessing activities.

In this respect it is telling that any social and environmental transformative potential of a CE has largely mutated into a technocratic transition (Stirling, 2015). The transition foreseen involves few if any changes to the existing social and economic relations, nor in the role of governments as 'guardians of the rules of the market'. In these ways the ideas of a CE in Sweden is a profoundly conservative project, a product of confidence in expert governance, in which large companies are considered to have the right, the will and the knowledge to reform industrial capitalism in a way that they deem to be sustainable.

Moreover, the mainstream CE narrative fails to problematize this transition in the context of critiques of capitalist economics from the perspectives of growth and consumerism (Jackson, 2009), distributional aspects (Piketty, 2014), or the tendency of capitalism to generate recurring crises (Harvey, 2010; Mirowski, 2014). This can be understood as an expression of a de-politicized or post-political condition (Straume and Humphrey, 2010; Swyngedouw, 2010; Valenzuela and Böhm, 2017), albeit one in which otherwise unheard voices (Ranciere 
1995) are welling up in the form of local struggles. The organization of a CE is not considered as being part of the political arena, but rather is understood as a managerial problem being solved by administrative mechanisms and institutions that all concur on the benevolence of green industrial growth (Blühdorn, 2004).

Depoliticization acts alongside ambiguity to give the CE concept more convening power. Different groups can organize around it even if their understandings and interests differ, especially if each group sees individual benefits. On the one hand, this can represent a 'rational utopia' (Ntsondé and Aggeri, 2019), with the hope that common CE visions, cognitive images and strategies will lead to more sustainable modes of living in practice. On the other hand, CE becomes not only an 'umbrella concept' as Blomsma and Brennan (2017) suggest, but also a 'floating signifier' (Laclau and Mouffe, 2001)), as the concept moves between and connects with diverse projects. In this respect, what matters is not the conceptual content of the signifier, "but rather, its filling-function or ... capacity to attract and organize different strands of filling-content" (Valenzuela and Böhm, 2017, p.34), Such a signifier provides "a singular representation which serves to institute or 'frame' meanings of universal reach, hegemonic dominance and a naturalized feel" (ibid).

CE includes tools for re-orienting waste management, retail, or industry towards more circular/sustainable practices and less wasteful material flows, but, much like the term 'sustainability' it is malleable and could be applied in ways that maintain the status quo as much as to facilitate transformative change. Lazarevic and Valve (2017) suggest that for CE proponents the vagueness characterizing the concept represents a deliberate short-term strategy for making it less controversial.

As a floating signifier the CE concept can therefore serve different purposes at different scales: it might stimulate reorganisation of business processes in particular corporations or industry branches, while at the same time, at the national level disempower calls for economic transformation and hide underlying environmental conflicts. This largely unspecified, beneficial generic form of the CE concept is mirrored in academic literature, and we urge scholars to question and explore the specific political economy of ideas of CE, and the business models they imply, as much as they examine the technological mechanics, or environmental implications of CE in particular business sectors.

In the discourses of the CE debate in Sweden, we see a set of practices that might be deployed not in ways that disrupt linear economies, but which stabilize existing interests' control over capital in the face of unstable world markets. For the companies the circular transition is partly about survival on a volatile market (Ellen MacArthur Foundation, 2013). CE strategies present large companies with opportunities to increase control of natural resources through governmental action. This means increased business control of resources, production chains, and consumption (through sharing, leasing, and repair, etc.).

For the broader interests of capital as a whole the commoditization of waste flows in a CE model (enabled by government regulation) can be understood as a means of opening a new sectoral arena in which to create and speculate on financial assets. Harvey (2010) describes such processes as typical strategies for capital renewal following periodic crises. In this respect the global timing of CE discourses might be seen as one consequence of the 2008 financial crisis. This increased control over capital and resources by companies facing political pressures, we term 'resilient capital'. 
Should we conclude that the unexpected consensus in the Swedish CE debate is a product of the harnessing of possible disruptive technologies by resilient capital to avoid economic transformation? Support for such an interpretation comes from Goldstein's (2018) description of the ways in which 'cleantech' innovations more generally are reconstructed by investors and venture capitalists as incremental technological enhancements to existing industrial processes. Despite aspirations for environmental and economic disruption through technological innovation Goldstein shows how the entrepreneurs involved are 'disciplined' by the investors and financiers so as to generate a more rapid return on investments, while the technologies are locked into deployments that bring limited environmental benefits.

The effectiveness of resilient capital in shaping the dominant discourse of CE in Sweden, with associated narratives of international competitiveness and job-creation, perhaps signals continued path towards 'sustaining' consumerism, extractivism, and (liberal) capitalism. But the potential remains for green values to subvert business strategies, or for material failures of corporate circularity initiatives to lead to policies more in keeping with the rhetoric of the concept, or for the rebalancing of the economy towards repair and craft skills to shift broader consumer values and make CE more disruptive in practice.

One of the main differences between previous studies and our result presented here is that the mainstream discourse in the scientific literature typically takes an instrumental understanding of the CE concept; it is understood almost solely as the application of 'science' and 'systems' thinking on material flows in order to reduce waste and environmental impact (Webster, 2017), thereby hiding political contentions. We have exposed these contentions, and our results could be used to improve CE studies at the Swedish scale and beyond. We particularly suggest a need for more attention to scale (national/local), to comparisons between national cultures and diverse sectors, and to stakeholder motivations in trying to develop practical policy. Future deliberative or ethnographic research will be needed to unpick the motivations and impacts of the diverse interests that have converged around the idea of a CE. But it is already clear that a superficial reading of the concept hides serious potential conflicts. If a CE is to deliver new values and lifestyles, or broader economic transformation, it will matter intensely what form it takes. 


\section{References}

Anshelm, J. (1995). Socialdemokraterna och miljöfrågan: en studie av framstegstankens paradoxer. Brutus Östlings bokförlag. Symposion.

Anshelm, J. (2002). Det gröna folkhemmet: striden om den ekologiska moderniseringen av Sverige. In Hedrén, J. (Ed.). (2002). Naturen som brytpunkt: Om miljöfrågans mystifieringar, konflikter och motsägelser. B. Östlings bokförlag. Symposion.

Anshelm, J. (2012). Kampen om klimatet: miljöpolitiska strider i Sverige 2006-2009. Pärspektiv.

Anshelm, J., Haikola, S., Wallsten, B. (2018a). Politicizing environmental governance - a case study of heterogeneous alliances and juridical struggles around the Ojnare Forest, Sweden. Geoforum, 91, 206-215.

Anshelm, J., Haikola, S., Wallsten, B. (2018b). Svensk gruvpolitik i omvandling: Aktörer, kontroverser, möjliga världar. Gidlunds Förlag.

Blomsma, F., Brennan, G. (2017). The Emergence of Circular Economy: A New Framing Around Prolonging Resource Productivity. Journal of Industrial Ecology, 21(3), 603-614.

Blühdorn, I. (2004). 'Post-ecologism and the politics of simulation'. In Wisseburg, M., Levy, Y. (Eds.) Liberal democracy and environmentalism: The end of environmentalism? London: Routledge.

Bocken, N. M., De Pauw, I., Bakker, C., van der Grinten, B. (2016). Product design and business model strategies for a circular economy. Journal of Industrial and Production Engineering, 33(5), 308-320.

Ellen MacArthur Foundation. (2013). Towards the circular economy, economic and business rationale for an accelerated transition. Ellen MacArthur Foundation: Cowes, UK.

Geissdoerfer, M., Savaget, P., Bocken, N. M., Hultink, E. J. (2017). The Circular Economy A new sustainability paradigm? Journal of Cleaner Production, 143, 757-768.

Geng, Y., Sarkis, J., Ulgiati, S., Zhang, P. (2013). Measuring China's circular economy. Science, 339(6127), 1526-1527.

Ghisellini, P., Cialani, C., Ulgiati, S. (2016). A review on circular economy: the expected transition to a balanced interplay of environmental and economic systems. Journal of Cleaner production, 114, 11-32.

Goldstein, J. (2018). Planetary improvement: Cleantech entrepreneurship and the contradictions of green capitalism. MIT Press.

Government Offices of Sweden. (GOS). (2016). Smart industry - a strategy for new industrialization for Sweden. Ministry of Enterprise and Innovation.

Harcourt, B. (2011). The Illusion of Free Markets. Punishment and the Myth of Natural Order. Harvard University Press.

Harvey, D. (2010). The enigma of capital: And the crises of capitalism. London: Profile. 
Hobson, K., Lynch, N. (2016). Diversifying and de-growing the circular economy: Radical social transformation in a resource-scarce world. Futures, 82, 15-25.

Hysing, E. (2014). A green star fading? A critical assessment of Swedish environmental policy change. Environmental Policy and Governance, 24(4), 262-274.

Jackson, T. (2009). Prosperity without growth: Economics for a finite planet. Routledge.

Johansson, B. (Ed.). (2011). Återvinna fosfor - hur bråttom är det? Forskningsrådet Formas.

Korhonen, J., Nuur, C., Feldmann, A., Birkie, S. E. (2018). Circular economy as an essentially contested concept. Journal of Cleaner Production, 175, 544-552.

Laclau, E., Mouffe, C. (2001). Hegemony and socialist strategy: Towards a radical democratic politics. London: Verso.

Landsorganisationen i Sverige. (LO). (2017). "Yttrande över remiss. Utredningen styrmedel för att förebygga uppkomst av avfall i syfte att främja en cirkulär ekonomi”.

Lazarevic, D., Valve, H. (2017). Narrating expectations for the circular economy: Towards a common and contested European transition. Energy Research \& Social Science, 31, 60-69.

Lewandowski, M. (2016). Designing the business models for circular economy-Towards the conceptual framework. Sustainability, 8(1), 43.

Lidskog, R., Elander, I. (2012). Ecological modernization in practice? The case of sustainable development in Sweden. Journal of Environmental Policy \& Planning, 14(4), 411-427.

Lundqvist, L. J. (2004). Sweden and ecological governance: Straddling the fence. Manchester University Press.

Mayring, P. (2004). Qualitative content analysis. In Flick, U., von Kardoff, E., Steinke, I. (Eds.). A companion to qualitative research. Sage.

Mirowski, P. (2013). Never let a serious crisis go to waste: How neoliberalism survived the financial meltdown. Verso Books.

Mol, A.P.J., Sonnenfeld, D.A., (eds.) (2000). Ecological Modernisation around the World: Perspectives and Critical Debates. Routledge

Moreau, V., Sahakian, M., Van Griethuysen, P., Vuille, F. (2017). Coming full circle: why social and institutional dimensions matter for the circular economy. Journal of Industrial Ecology, 21(3), 497-506.

Murray, A., Skene, K., Haynes, K. (2017). The circular economy: an interdisciplinary exploration of the concept and application in a global context. Journal of Business Ethics, 140(3), 369-380.

Ntsondé, J., Aggeri, F. (2019). Circular economy as a performative concept based on a rational utopia. EGOS, Jul 2019, Edinburgh, United Kingdom. hal-02168910.

Nyberg, M. (2019, September). Preem vill bygga ut - boende i närheten är rädda. Expressen. 
Persson, S., Harnesk, D., Islar, M. (2017). What local people? Examining the Gállok mining conflict and the rights of the Sámi population in terms of justice and power. Geoforum, 86, 20-29.

Piketty, T. (2014). Capital in the Twenty-First Century. Cambridge Massachusetts: The Belknap Press of Harvard University Press.

Ranciere, J. (1995). On the Shores of Politics. London: Verso.

Report from the Commission to the European Parliament, the Council, the European Economic and Social Committee and the Committee of the Regions on the implementation of the Circular Economy Action Plan. (2019). COM(2019) 190 final.

Retriever. (2020). Mediearkivet. https://www.retriever.se/product/mediearkivet/ [Last visited: 2020-02-28].

Rieke, D., Vermeulen, W. J. V., Witjes, S. (2018). The circular economy: New or Refurbished as CE 3.0? Resources, Conservation and Recycling, 135, 246-264.

Riff, D., Lacy, S., Fico, F., Watson, B. (2019). Analyzing media messages: Using quantitative content analysis in research. Routledge.

Sjöstrand, Y. S. (2014). Stadens sopor: Tillvaratagande, förbränning och tippning $i$ Stockholm 1900-1975. Nordic Academic Press.

Skene, K. R. (2018). Circles, spirals, pyramids and cubes: why the circular economy cannot work. Sustainability Science, 13(2), 479-492.

SOU 2017:22. (2017). Från värdekedja till värdecykel - så får Sverige en mer cirkulär ekonomi. Elanders Sverige AB: Stockholm.

Stahel, W. R. (2013). The business angle of a circular economy-higher competitiveness, higher resource security and material efficiency. Ellen McArthur Foundation.

Stirling, A. (2015). Emancipating transformations: from controlling 'the transition' to culturing plural radical progress. In Scoones, I., Newell, P., Leach, M. (Eds.) The politics of green transformations. Routledge.

Straume, I., Humphrey, J. (2010). Depoliticization: The political imaginary of capitalism. Malmö: NSU Press.

Su, B., Heshmati, A., Geng, Y., Yu, X. (2013). A review of the circular economy in China: moving from rhetoric to implementation. Journal of Cleaner Production, 42, 215-227.

Swyngedouw, E. (2010). 'Impossible sustainability and the post-political condition'. In Cerreta, M., Concilio, G., Monno, V. (Eds.) Making strategies in spatial planning. Amsterdam: Springer.

Temesgen, A., Storsletten, V., Jakobsen, O. (2019). Circular Economy - Reducing Symptoms or Radical Change? Philosophy of Management, 1-20.

The Standing Committee of the People's Congress of the People's Republic of China. (2008). Law on Promoting Circular Economy. 
Tukker, A. (2015). Product services for a resource-efficient and circular economy - a review. Journal of Cleaner Production, 97, 76-91.

Valenzuela, F., Böhm, S. (2017). Against wasted politics: A critique of the circular economy. ephemera: theory \& politics in organization, 17(1), 23-60.

Webster, K. (2017). The Circular Economy: A Wealth of Flows (2nd Edition). Cowes: Ellen Macarthur Foundation.

Winans, K., Kendall, A., Deng, H. (2017). The history and current applications of the circular economy concept. Renewable and Sustainable Energy Reviews, 68, 825-833.

Yuan, Z., Bi, J., Moriguichi, Y. (2006). The circular economy: A new development strategy in China. Journal of Industrial Ecology, 10(1-2), 4-8.

Zink, T., Geyer, R. (2017). Circular economy rebound. Journal of Industrial Ecology, 21(3), 593-602. 